\title{
Investigation of Some Vitamin Type Inhibition on Human Cord Blood Carbonic Anhydrase I and II
}

\author{
Bazı Vitaminlerin Insan Kordon Kanı Karbonik Anhidraz I ve II Üzerine İnhibisyon Tiplerinin \\ Incelenmesi
}

\author{
Ahmet Çetin', Taha Abdulkadir Çoban², Murat Çankaya³, Ümit Naykı', Mehmet Kuzucu ${ }^{5}$ \\ 'Department of Chemistry, Faculty of Science and Letters, Erzincan University, Erzincan, Turkey \\ 2Department of Biochemistry, Faculty of Medicine, Erzincan University, Erzincan, Turkey \\ ${ }^{3}$ Department of Biology, Faculty of Science and Letters, Erzincan University, Erzincan, Turkey \\ ${ }^{4}$ Department of Obstetrics and Gynecology, Faculty of Medicine, Erzincan University, Erzincan, Turkey \\ ${ }^{5}$ Department of Biology, Faculty of Science and Letters, Erzincan University, Erzincan, Turkey
}

\begin{abstract}
Objective: Human cord blood, a specialized blood tissue, contains many substances including several enzymes which act by different biochemical reactions. Carbonic anhydrase (CA) isoenzymes are one of the most important enzyme family which are crucial for living organisms to survive. However, there is limited data regarding the effect of vitamins on CA isoenzymes. The aim of this study is to test the inhibitory effect of some widely used vitamins on human cord blood CA I and II (hcbCA I and hcbCA II).
\end{abstract}

Methods: We purified hcbCA I and hcbCA II from human cord blood erythrocytes by Sepharose-4B-I-tyrosine-sulfanilamide affinity gel chromatography. The inhibitory effects of vitamin A (retinol), vitamin B12 (cyanocobalamin) and vitamin $\mathrm{K}$ (menadione sodium bisulfate, k3) on two isoenzyme were checked using $I C_{50}$ values.

Result: $\mathrm{IC}_{50}$ values for vitamin A, vitamin B12 and vitamin $\mathrm{K}$ were found to be 44,90 , and $31 \mu \mathrm{M}$ for hcbCA I and of 51, 62, and $21 \mu \mathrm{M}$ for hcbCA II; respectively. All these substances were found to be non-competitive inhibitors.

Conclusion: Vitamins are vitally important for continuation of life and activity of some of enzymes. While the physicans recommend pregnant women to take vitamins during pregnancy, we suggest that the findings obtained in this study be taken into consideration. (JAREM 2013; 3: 79-83)

Key Words: Cord blood, vitamins, carbonic anhydrase, inhibition effect

\section{ÖZET}

Amaç: İnsan kordon kanı, farklı biyokimyasal reaksiyonların oluşumunda rol alan enzimler gibi birçok maddeyi içeren özeleşmiş bir kan dokusudur. Karbonik anhidraz (CA) izoenzimleri canlı organizmaların hayatta kalmaları için gerekli olan en önemli enzim ailelerden biridir. Fakat Vitaminlerin CA izoenzimleri üzerine etkileri hakkında yeterli bilgi bulunmamaktadır. Bu çalışmanın amacı, yaygın olarak kullanılan bazı vitaminlerin insan kordon kanından saflaştırılan CA I ve II üzerine in vitro etkilerini araştırmaktır.

Yöntemler: Insan kordon kanı eritrositlerden hcbCA I ve II hcbCA izo enzimleri Sefaroz-4B-L-tirozin-sülfamid afinite jel kromatografisi kullanılarak saflaştıııldı. İki izoenzim üzerine A vitamini (retinol), B12 vitamini (Siyanokobalamin) ve K vitamini (menadion sodyum bisülfat, K3) inhibisyon etkileri IC ${ }_{50}$ değerleri kullanılarak kontrol edildi.

Bulgular: Sırasıyla, A vitamini, B12 vitamini ve K vitamini için IC50 değerleri hcbCA I için $21 \mu \mathrm{M}, 90 \mu \mathrm{M}, 44 \mu \mathrm{M}$ ve hcbCA II için $51 \mu \mathrm{M}, 62 \mu \mathrm{M}, 31 \mu \mathrm{M}$ olarak bulunmuştur. Çalışılan vitaminlerin, yarışmasız inhibisyon gösterdiği bulundu.

Sonuç: Vitaminler bazı enzimlerin aktivitleri ve hayatın devamı için oldukça önemlidir. Doktorlar, gebelikte vitamin desteği önerisinde bulunurken çalışmamızda elde ettiğimiz sonuçları da dikkate almalarını öneririz. (JAREM 2013; 3: 79-83)

Anahtar Sözcükler: Kordon kanı, vitaminler, karbonik anhidraz, inhibisyon etkisi

\section{INTRODUCTION}

Recently, cord blood has become one of the major areas of interest in science. For instance; cord blood stem cells are currently used in the treatment of several life-threatening diseases such as cancer, genetic diseases, and blood disorders. Determination of the kinetic properties of cord blood has become very important today $(1,2)$. Cord blood contains many enzyme and these enzymes are very important for the life attendance. One important family is the carbonic anhydrases, which catalyze the reversible reactions of $\mathrm{CO}_{2}$ and water (3). CA is of broad interest because it is one of the fastest enzymes known; the turnover number or kcat of some CA isoforms exceeds $\left(1 \times 10^{6} \mathrm{~s}^{-1}\right)$ (4). In addition, the reactions of CA isoenzymes are essential to several physiological processes such as calcification, photosynthesis, respiration, ionic, acid-base and fluid balance, metabolism and cell growth (5).

Classification of Vitamins is divided into two groups, such as according to biological and chemical activity, but not their structure. Vitamins analysed according to their biochemical function mainly are divided into two groups; first, some of them are organometallic compounds with important metabolic derivatives that act as cofactors faor certain enzymes. Those in the second group have an antioxidant activity. Both functions are important 
for fulfilling activities of enzymes and elimination of oxidant substances. A number of investigations have reported vitamin A (retinol), vitamin B12 (cyanocobalamin) and vitamin K (menadione, k3) (Fig. 1) as having exhibited beneficial effects on the regulation of metabolism (6-8).

Cyanocobalamin contributes to the optimal functioning of the central nervous system through its role as cofactor in numerous catalytic reactions in the human body, which are required for neurotransmitter synthesis and functioning and myelination of the spinal cord and brain $(9,10)$. Vitamin $A$ is a vital nutrient for humans and is converted to the visual chromophore, 11-cisretinal, and to the hormone, retinoic acid (11). Vitamin $\mathrm{K}$ is another important essential molecule in nutrients. This molecule is associated with the blood-clotting cascade. Vitamin $\mathrm{K}$ has three different molecules and one of them is menadione (Vitamin K3). Most of the researches are focused on menadione. It was used as an oxidative model for the explanation of anticancer effects both in vitro and in vivo (12). On the other hand, dosages of vitamins are important for regulation of metabolism. It was shown that vitamins have inhibitory effects on some enzymes. Menadione inhibited the lactoperoxidase activity. It demonstrated competitive inhibition. Also, milk xanthine oxidase was inhibited by folic and ascorbic acids. Also, it demonstrated non-competitive inhibition on adenylate kinase (13-15).

Human cord blood carbonic anhydrases I, and II are important for the reversible hydration of carbon dioxide $\left(\mathrm{CO}_{2}\right)$ to bicarbonate $\left(\mathrm{HCO}_{3}\right)$ with production of a proton $\left(\mathrm{H}^{+}\right)$. As known, all of these vitamins are commonly used during pregnancy. Vitamins show inhibitory effects on enzymes (13-15). However, their dosage in different organisms must be investigated carefully in the light of these inhibitory actions. It is important to identify the enzyme activities during pregnancy and characterize the factors increasing or decreasing those activities. Therefore, in an effort to provide beneficial data for further investigations, the present study aimed to evaluate the in vitro effects of commonly used vitamins on hcbCA I and hcbCA II isoenzymes.

\section{METHODS}

\section{Chemicals}

Sepharose 4B, protein assay reagents and 4-nitrophenylacetate were obtained from Sigma-Aldrich Co. (Sigma-Aldrich Chemie GmbH Export Department Eschenstrasse 5, 82024 Taufkirchen, Germany). All other chemicals were analytical grade and obtained from Merck (Merck KGaA Frankfurter strasse 250, D 64293 Darmstadt Germany).

\section{Purification of carbonic anhydrase isozymes from human cord blood by affinity chromatography}

The purification of the both hcbCA isoenzymes was performed in a single-step method by means of Sepharose-4B-L tyrosinesulphanilamide affinity gel chromatography. Firstly, we obtained letters of consent from patients before cesarean section and normal delivery. Then we got fresh human cord blood obtained from the Blood Centre of Erzincan Hospital. Erythrocytes were purified from this fresh blood. The blood samples were centrifuged at 2250xg for $15 \mathrm{~min}$ and the plasma and buffy coat were removed. The red cells were isolated and then washed twice with $\mathrm{NaCl}(0.9 \%)$ and haemolysed with 1.5 volumes of ice-cold water. The ghost and intact cells were removed by centrifuga- tion at $14500 \times \mathrm{g}$ for $30 \mathrm{~min}$ at $4^{\circ} \mathrm{C}$. The $\mathrm{pH}$ of the haemolysate was adjusted to 8.7 with solid Tris. CNBr-activated-Sepharose $4 \mathrm{~B}$ was filtered by a Buchner funnel and washed with cold $\mathrm{NaH}$ $\mathrm{CO}_{3}$ buffer $(0.1 \mathrm{M}, \mathrm{pH}$ 10.0). L-Tyrosine by using saturated Ltyrosine solution in the same buffer was coupled to Sepharose 4B-L-tyrosine activated with CNBr. The affinity gel was obtained by diazotization of sulphanilamide and coupling of this compound to the Sepharose 4B-L-Tyrosine. After 10 minutes of reaction, the diazotized sulphanilamide was poured into $40 \mathrm{~mL}$ of the Sepharose 4B-L-Tyrosine suspension. The $\mathrm{pH}$ was adjusted to 9.5 with $1 \mathrm{M} \mathrm{NaOH}$. After gentle stirring for 3 hours at room temperature, the coupled red Sepharose derivative was washed with $1 \mathrm{~L}$ of water and then $200 \mathrm{~mL}$ of Tris-sulphate $(0.05 \mathrm{M} \mathrm{pH}$ 7.5). The haemolysate was applied to the prepared Sepharose-4B-L tyrosine-sulphanilamide affinity column equilibrated with $25 \mathrm{mM}$ Tris- $\mathrm{HCl} / 0.1 \mathrm{M} \mathrm{Na}_{2} \mathrm{SO}_{4}(\mathrm{pH}$ 8.7). The affinity gel was washed with $25 \mathrm{mM}$ Tris- $\mathrm{HCl} / 22 \mathrm{mM} \mathrm{Na}_{2} \mathrm{SO}_{4}$ (pH 8.7). The human cord blood carbonic anhydrase (hcbCA I and hcbCA II) isozymes were eluted with $1 \mathrm{M} \mathrm{NaCl} / 25 \mathrm{mM} \mathrm{Na}_{2} \mathrm{HPO}_{4}(\mathrm{pH}$ 6.3) and $0.1 \mathrm{M} \mathrm{CH}_{3} \mathrm{COONa} / 0.5 \mathrm{M} \mathrm{NaClO}_{4}(\mathrm{pH} 5.6)$, respectively. All procedures were performed at $4^{\circ} \mathrm{C}(16,17)$.

\section{Hydratase activity assay}

CA activity was assayed by following the hydration of $\mathrm{CO}_{2}$ according to the method described by Ozturk Sarikaya et al. (18). Enzyme unit (EU) of $\mathrm{CO}_{2}$-hydratase activity was calculated by using the following equation $\left(t_{0}-t_{c} / t_{c}\right)$ where $t_{o}$ and $t_{c}$ are the times for $\mathrm{pH}$ change of the non-enzymatic and the enzymatic reactions, respectively.

\section{Esterase activity assay}

CA activity was assayed according to the method described by Innocenti et al. $(19,20)$. CA activity was determined by following the change in absorbance at $348 \mathrm{~nm}$ of 4-nitrophenylacetate (NPA) to 4-nitrophenylate ions over a period of $3 \mathrm{~min}$ at $25^{\circ} \mathrm{C}$ using a spectrophotometer (CHEBIOS UV-VIS) according to the method described by Verpoorte et al. (21). The enzymatic reaction, in a total volume of $3.0 \mathrm{~mL}$, contained $1.4 \mathrm{~mL}$ $0.05 \mathrm{M}_{\text {Tris- }} \mathrm{SO}_{4}$ buffer ( $\mathrm{pH}$ 7.4), 4-nitrophenylacetate $(1 \mathrm{~mL}, 3$ $\mathrm{mM}), \mathrm{H}_{2} \mathrm{O}(0.5 \mathrm{~mL})$ and enzyme solution $(0.1 \mathrm{~mL})$. A reference measurement was obtained by preparing the same cuvette without enzyme solution. The inhibitory effects of $A$ (retinol), vitamin B12 (cyanocobalamin) and vitamin K (menadione sodium bisulfate, k3) were examined. All compounds were tested in triplicate at each concentration used. Different inhibitor concentrations were used. The activity of the control cuvette was accepted as 100\%. For each inhibitor, activity (\%)-[Vitamins] graphs were drawn. For determination of Ki values, three different vitamin concentrations were tested. In these experiments, 4-nitrophenylacetate was used as substrate at five different concentrations (0.15-0.75 mM). The Lineweaver-Burk curves were drawn (22).

\section{Protein determination}

Protein during the purification steps was determined spectrophotometrically at $595 \mathrm{~nm}$ according to the Bradford method (23), using bovine serum albumin as the standard.

\section{SDS polyacrylamide gel electrophoresis}

SDS polyacrylamide gel electrophoresis was performed after purification of the cord blood isoenzymes. It was carried out in 
Table 1. Purification scheme of CA I, and CA II from human cord blood erythrocytes

\begin{tabular}{|l|c|c|c|c|c|c|c|c|}
\hline Step & $\begin{array}{c}\text { Activity } \\
(\mathbf{E U} / \mathbf{m L})\end{array}$ & $\begin{array}{c}\text { Total Volume } \\
(\mathbf{m L})\end{array}$ & $\begin{array}{c}\text { Protein } \\
(\mathbf{m g} / \mathbf{m L})\end{array}$ & $\begin{array}{c}\text { Total } \\
\text { Protein }(\mathbf{m g})\end{array}$ & $\begin{array}{c}\text { Total Activity } \\
(\mathbf{E U})\end{array}$ & $\begin{array}{c}\text { Specific } \\
\text { Activity } \\
(\mathbf{E U} / \mathbf{m g})\end{array}$ & $\begin{array}{c}\text { Recovery } \\
(\%)\end{array}$ & $\begin{array}{c}\text { Purification } \\
(\text { Fold) }\end{array}$ \\
\hline Haemolysate & 138.00 & 50.00 & 17.70 & 885 & 6901.00 & 7.793 & 100 \\
\hline hcbCA I & 417.60 & 12.50 & 0.3528 & 4.41 & 5220.00 & 1183.67 & 75.64 & 151.88 \\
\hline hcbCA II & 747.12 & $6 . .60$ & 0.1181 & 0.78 & 4931.00 & 6321.79 & 71.45 & 811.21 \\
\hline EU: Enzyme unit & & & & & & &
\end{tabular}

Table 2. Inhibitory activities of vitamins

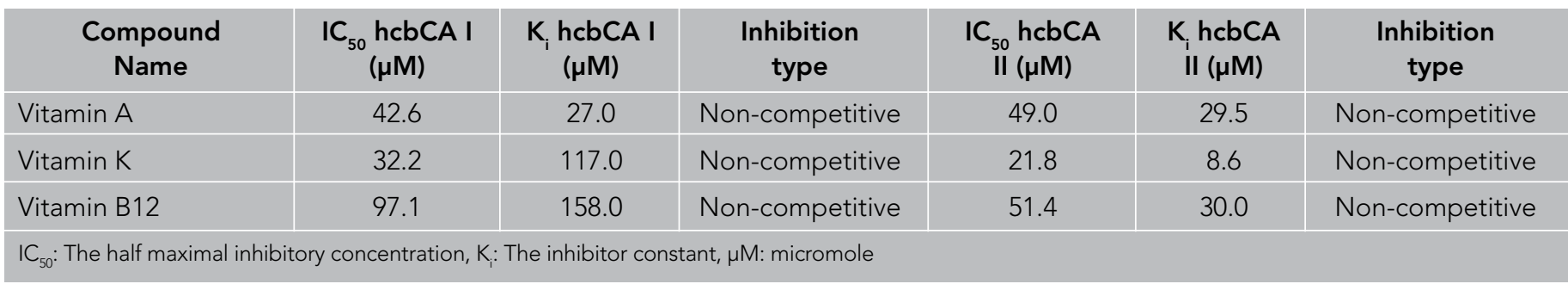

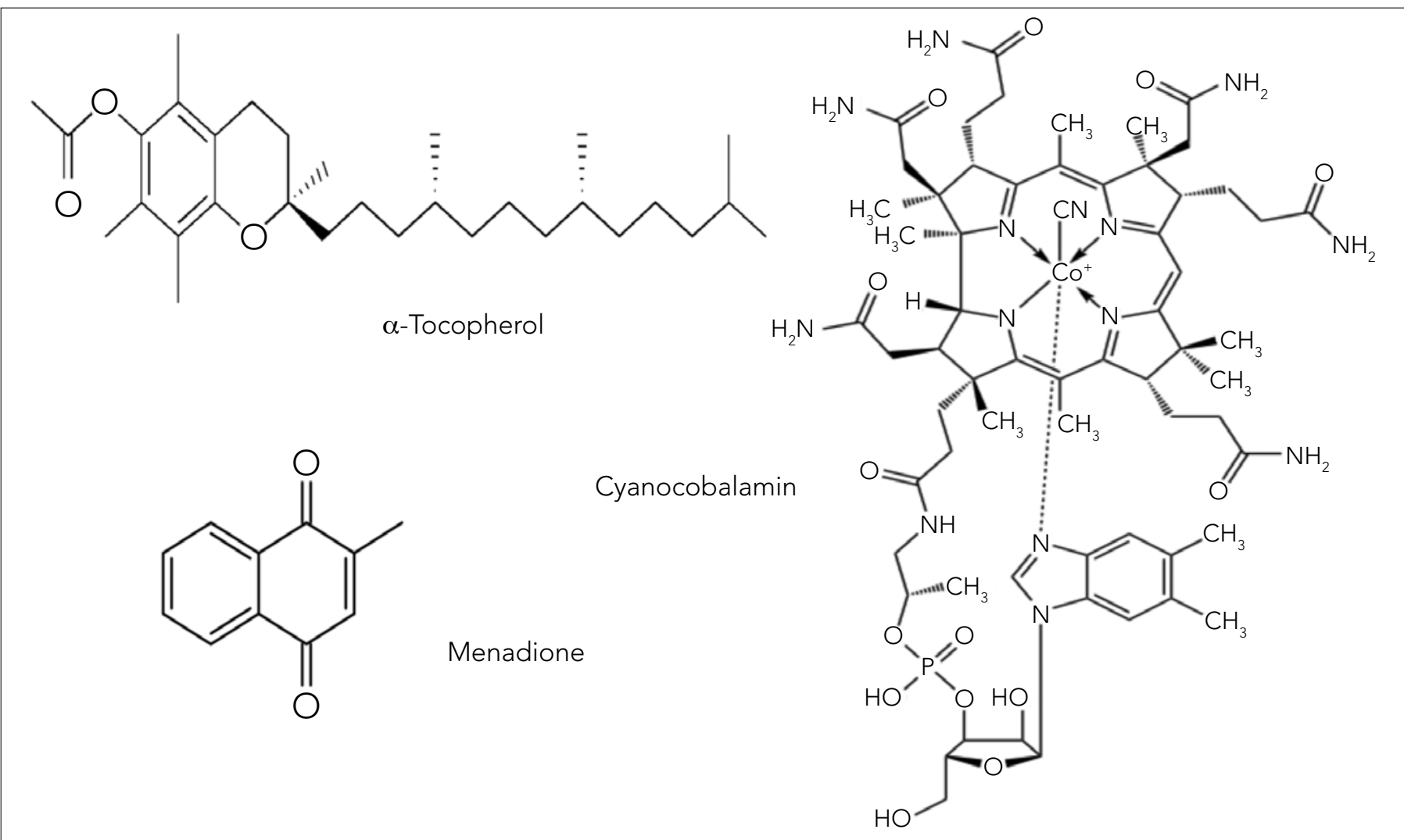

Figure 1. Chemical structures of tested vitamins

$10 \%$ and $3 \%$ acrylamide for the running and the stacking gel, respectively, containing SDS (0.1\%) according to the Laemmli procedure (24). A $20 \mathrm{mg}$ sample was applied to the electrophoresis medium. Gels were stained for $1.5 \mathrm{~h}$ in Coomassie-Brilliant Blue R-250 (0.1\%) in methanol (50\%) and acetic acid (10\%), and then destained with several changes of the same solvent without the dye. The electrophoretic pattern was photographed (Fig. 2).

\section{Statistical evaluation}

This study does not need any statistical hypothesis testing.

\section{RESULTS}

CA I, and II from human cord blood erythrocytes were purified by a simple step procedure using Sepharose 4B L-tyrosine sulphanilamide affinity column. As can be seen in Table 1, hcbCA I was 


\section{$175 \mathrm{kDa}$}

\section{$80 \mathrm{kDa}$}

\section{$58 \mathrm{kDa}$ \\ $46 \mathrm{kDa}$}

\section{$24 \mathrm{kDa}$}

b

Figure 2. SDS-PAGE zymogram. Lane a, hcbCA II, line $c$, hcbCA I, line $b$, standard proteins, Standard proteins: 1) MBP (Maltose-binding protein- $\beta$ - galactosidase, $175 \mathrm{kDa}), 2$ ) MBP (Maltose binding protein)paramyosin (fusion of MBP and paramyosin, $80 \mathrm{kDa}$ ), 3) MBP-CBD (Chitin binding domain, fusion of MBP and chitin binding domain, 58 $\mathrm{kDa}$ ), 4) CBD-Mxe Intein-2CBD (Fusion of the chitin binding domain and the Mxe Intein followed by two chitin binding domains, $46 \mathrm{kDa}$ ). 5) soybean trypsin inhibitor ( $24 \mathrm{kDa}$ )

purified 151.88-fold with specific activity (1183.67 EU mg $\mathrm{m}^{-1}$ ) and yield (75.64\%). On the other hand, hcbCA II was purified 811.21fold with specific activity (6321.79 $\mathrm{EU} \mathrm{mg}^{-1}$ ) and yield (71.45\%). SDS-PAGE zymograme of both isoenzymes showed a single band (Fig. 2). Three inhibitors [vitamin A (Retinol), vitamin B12 (cyanocobalamin) and vitamin K (menadione, k3)] were prepared and evaluated for the inhibitory effects on hcbCA I, and II. The inhibitory effects of these vitamins were tested in the range of 0.001-1000 mM. All vitamins showed inhibitory effects on hcbCA $\mathrm{I}$, and hcbCA II, under in vitro conditions. $I_{50}$ values were calculated by Activity (\%)-[Vitamins] graphs and are given in Table 2. K values were calculated from Lineweaver-Burk graphs $(21,22)$ and are given in Table 2 .

\section{DISCUSSION}

Cord blood is an alternative stem cell source for treating cancer and genetic diseases. Therefore, analysing the enzyme property of cord blood is crucial for the organism. Umbilical cord blood contains different enzymes such as glucose 6-phosphate dehydrogenase, glutathione reductase and carbonic anhydrases $(25,26)$. CA included 16 different isoforms, which are found in different tissue and organisms. Most of the investigations focused on CA I, and II, because they were extracted from blood erythrocytes. CA I, and CA II were purified by affinity column chromatography. The effects of various chemicals, pesticides and drugs on its activity have been investigated (16-20).

Vitamins are organic compounds required by an organism as a vital nutrient in limited amounts (27). Thirteen vitamins are universally recognized at present. Some of them show hormonelike functions as regulators of mineral metabolism, or regulators of cell and tissue growth and differentiation (28). Vitamin A

refers to the compounds retinal, retinol and its esters, whereas provitamin A refers to the carotenoids $\beta$-cryptoxanthin (29). Vitamin $A$ is indispensable for cell differentiation, embryonic development and vision, besides many other roles (e.g. glycoprotein synthesis, carcinogenesis, growth hormone production) $(30,31)$. Vitamin B12 is an important water-soluble vitamin that regulates red blood cell, neural cell activity and displays antioxidant properties and modulates nucleic acid metabolism and gene regulation $(32,33)$. It is generally used as a therapeutic agent and supplement, because of its efficacy and stability $(34,35)$. All of these investigations exhibited vitamins important for continuation of life.

Vitamin A, vitamin B12, and vitamin K3 have many benefits for organisms, but some investigations have revealed that these three vitamins have inhibitory actions on some enzymes. Vitamin K3 showed competitive inhibition on lactoperoxsidase ${ }^{14}$, another investigation reported, this vitamin has inhibitory effects on human mitochondria DNA polymerase gamma (pol gamma) (36). Vitamin K3 has inhibitory effects on aldehyde oxidase (37). Some of the researches exhibited the effects of some vitamins on carbonic anhydrase (CA). For example, Mraz and friends checked the effect of vitamin D on the activity of erythrocyte carbonic anhydrase isoenzymes (CA) in vitro and in vivo. Vitamin D inhibited CA I, and CA II $(38,39)$. There is not much detailed study regarding the effect of vitamins on CAs activity. In this study, vitamins which are important during life were investigated for their inhibitory effects on hcbCAl and hcbCAll in vitro, and their kinetic constants $\left(\mathrm{K}_{\mathrm{i}}\right.$ and $\mathrm{IC}_{50}$ values) were reported. This study showed that vitamins had strong inhibitory effects on hcbCAl and hcbCAll activity, which have not been reported previously. As evident from $\mathrm{IC}_{50}$ values, hcbCA I, and hcbCA II inhibition by vitamin $\mathrm{K}$ are higher than vitamin $\mathrm{A}$ and vitamin B12, respectively. $I_{50}$ values correlate with the Ki values of the vitamin as shown in Table 2.

\section{CONCLUSION}

We believe that the results of this study should draw attention to the use of vitamins throughout the whole life period, since CAs have a part in the interconversion of $\mathrm{CO}_{2}$ and water to $\mathrm{HCO}_{3}$ and $\mathrm{H}^{+}$; use of vitamins may decrease hcbCA I and hcbCA II activity in human cord blood erythrocytes. If it is necessary to give these vitamins during pregnancy, their dosage should be very carefully considered to decrease the potential side effects. Investigations of the in vitro effects of these vitamins on hcbCA I and hcbCA II activity is more important from a clinical point of view and for this reason, detailed studies are required.

\section{Conflict of Interest}

No conflict of interest was declared by the authors.

Financial Disclosure: This work was funded by grants from of Erzincan University (Project no: 2010/16).

Peer-review: Internally peer-reviewed.

Ethics Committee Approval: Ethics committee approval was received for this study from the ethics committee of Erzincan University School of Medicine (Date: 15.12.2010, protocol no: 5/1).

Informed Consent: Written informed consent was obtained from patients who participated in this study. 


\section{Author Contributions}

Concept - T.A.Ç., M.Ç., U.N., A.Ç., M.K.; Design - T.A.Ç., M.Ç., U.N., A.Ç., M.K.; Supervision - T.A.Ç., M.Ç., U.N., A.Ç., M.K.; Funding - T.A.Ç., M.Ç., U.N., A.Ç., M.K.; Materials - T.A.Ç., U.N., A.Ç., M.K.; Data Collection and/ or Processing - T.A.Ç., M.Ç., U.N., A.Ç., M.K.; Analysis and/or Interpretation - T.A.Ç., M.Ç., U.N.; Literature Review - T.A.Ç., M.Ç., U.N., A.Ç., M.K.; Writing - T.A.Ç., M.Ç., U.N.; Critical Review - T.A.Ç., M.Ç., U.N., A.Ç., M.K.

\section{Çıkar Çatışması}

Yazarlar herhangi bir çıkar çatışması bildirmemişlerdir.

Finansal Destek: Bu çalışma Erzincan Üniversitesi araştırma fonu tarafından desteklenmiştir (Proje No: 2010/06).

Hakem değerlendirmesi: i̇ç değerlendirme.

Etik Komite Onayı: Bu çalışma için etik komite olayı Erzincan Üniversitesi Tıp Fakültesi'nden (Tarih: 15.12.2010, protokol no: 5/1) alınmıştır.

Hasta Onamı: Yazılı hasta onamı bu çalışmaya katılan hastalardan alınmıştır.

\section{Yazar Katkıları}

Fikir - T.A.Ç., M.Ç., U.N., A.Ç., M.K.; Tasarım - T.A.Ç., M.Ç., U.N., A.Ç., M.K.; Denetleme - T.A.Ç., M.Ç., U.N., A.Ç., M.K.; Kaynaklar - T.A.Ç., M.Ç., U.N., A.Ç., M.K.; Malzemeler - T.A.Ç., U.N., A.Ç., M.K.; Veri toplanması ve/veya işlemesi - T.A.Ç., M.Ç., U.N., A.Ç., M.K.; Analiz ve/ veya yorum - T.A.Ç., M.Ç., U.N.; Literatür taraması - T.A.Ç., M.Ç., U.N., A.Ç., M.K.; Yazıyı yazan - T.A.Ç., M.Ç., U.N.; Eleştirel İnceleme - T.A.Ç., M.Ç., U.N., A.Ç., M.K.

\section{REFERENCES}

1. Cairo MS, Wagner JE. Placental and/or umbilical cord blood: an alternative source of hematopoietic stem cells for transplantation. Blood 1997; 90: 4665-78.

2. Umbilical Cord Issues/Delayed Cord Clamping, gentlebirth.org

3. Meldrum NU, Roughton FJW. Carbonic anhydrase. Its preparation and properties. J Physiol 1933; 80: 113-42.

4. Chegwidden WR, Carter ND. Introduction to the carbonic anhydrases. EXS 2000; 90: 13-28.

5. Tashian RE, Hewett-Emmett D, Carter N, Bergenhem NCH. Carbonic anhydrase (CA)-related proteins (CA-RPs), and transmembrane proteins with CA or CA-RP domains. In: Chegwidden WR, Carter N, Edwards YH. (Eds.), The Carbonic Anhydrases. New Horizons, Birkhäuser Verlag, Basel, Switzerland 2000.p.105-20. [CrossRef]

6. McCollum EV, Simmonds N, Becker JE, Shipley PG. Studies on experimental rickets: $\mathrm{XXI}$. an experimental demonstration of the existence of a vitamin which promotes calcium deposition. J Biol Chem 1922; 53: 293-8.

7. Sugden C. One-carbon metabolism in psychiatric illness. Nutr Res Rev 2006; 19: 117-36. [CrossRef]

8. Guilarte TR. Vitamin B6 and cognitive development: recent research findings from human and animal studies. Nutr Rev 1993; 51: 193-8. [CrossRef]

9. Lamson DW, Plaza SM. The anticancer effects of vitamin K. Altern Med Rev 2003; 8: 303-13.

10. Dror DK, Allen LH. Effect of vitamin B12 deficiency on neurodevelopment in infants: current knowledge and possible mechanisms. Nutr Rev 2008; 66: 250-5. [CrossRef]

11. Harrison EH. Mechanisms involved in the intestinal absorption of dietary vitamin A and provitamin A carotenoids. Biochim Biophys Acta 2012; 1821: 70-7. [CrossRef]

12. Lamson DW, Plaza SM. The anticancer effects of vitamin K. Altern Med Rev 2003; 8: 303-12.

13. Nishino T, Tsushima K. Interaction of milk xanthine oxidase with folic acid. Inhibition of milk xanthine oxidase by folic acid and separation of the enzyme into two fractions on Sepharose 4B/folate gel. J Biol Chem 1986; 261: 11242-6.
14. Sisecioglu M, Cankaya M, Ozdemir H. Effects of Some Vitamins on Lactoperoxidase Enzyme Activity. Int J Vitam Nutr Res 2009; 79: 188-94. [CrossRef]

15. Russell PJ, Williams A, Gapuz D. Inhibition of rabbit muscle adenylate kinase by vitamin C. Biochem Biophys Res Commun 1997; 233: 386-8. [CrossRef]

16. Cankaya M, Aktas M, Kuzucu M, Gül I, Coban TA. Effects of some drugs on human cord blood erythrocyte carbonic anhydrases and II: an in vitro study. J Enzyme Inhib Med Chem 2012; 27: 641-5. [CrossRef]

17. Coban TA, Beydemir S, Gulcin I, Ekinci D. Morphine inhibits erythrocyte carbonic anhydrase in vitro and in vivo. Biol Pharm Bull 2007; 30: 2257-61. [CrossRef]

18. Ozturk Sarıkaya SB, Gulcin I, Supuran CT. Carbonic anhydrase inhibitors. Inhibition of human erythrocyte isozymes I and II with a series of phenolic acids. Chem Biol Drug Des 2010; 75: 515-20. [CrossRef]

19. Innocenti A, Beyza Oztürk Sarikaya S, Gülçin I, Supuran CT. Carbonic anhydrase inhibitors. Inhibition of mammalian isoforms I-XIV with a series of natural product polyphenols and phenolic acids. Bioorgan Med Chem 2010; 18: 2159-64. [CrossRef]

20. Innocenti A, Gulcin I, Scozzafava A, Supuran CT. Carbonic anhydrase inhibitors. Antioxidant polyphenol natural products effectively inhibit mammalian isoforms I-XV. Bioorgan Med Chem 2010; 20: 5050-3 [CrossRef]

21. Verpoorte JA, Mehta S, Edsall J T. Esterase activities of human carbonic anhydrases B and C J Bio Chem 1967 242: 4221-6.

22. Lineweaver H, Burk DJ. The Determination of Enzyme Dissociation Constants. Am Chem Soc 1934; 56: 658-66. [CrossRef]

23. Bradford M. A rapid and sensitive method for quantitation of microgram quantities of protein utilizing the principle of protein-dyebinding. Anal Biochem 1976; 72: 248. [CrossRef]

24. Laemmli DK. Clevage of structual proteins during in assembly of the head of bacteriophage T4. Nature 1970; 227:680-5. [CrossRef]

25. Ciftçi M, Küfrevioglu OI, Gündogdu M, Ozmen I. Effects of some antibiotics on enzyme activity of glucose-6-phosphate dehydrogenase from human erythrocytes. Pharmacol Res 2000; 41:109-13. [CrossRef]

26. Esbaugh AJ, Tufts BL. The structure and function of carbonic anhydrase isozymes in the respiratory system of vertebrates Respir Physiol Neurobiol 2006; 154: 185-98. [CrossRef]

27. Lieberman S, Bruning N. The Real Vitamin \& Mineral Book NY: Avery Group 1990.

28. Bender DA Nutritional biochemistry of the vitamins Cambridge UK: Cambridge University Press, 2003.

29. Nomenclature policy: generic descriptors and trivial names for vitamin A and related compounds. J Nutr 1984; 114: 643-4.

30. Underwood BA, Arthur P. The contribution of vitamin A to public health. FASEB J 1996; 10: 1040-8.

31. Marceau G, Gallot D, Lemery D, Sapin V. Metabolism of retinol during mammalian placental and embryonic development. Vitam Horm 2007; 75: 97-115. [CrossRef]

32. Cadogan MP. CPR decision making and older adults: clinical implications. J Gerontol Nurs 2010; 36: 16-21. [CrossRef]

33. Gülçin I. Antioxidant activity of food constituents: an overview. Arch Toxicol 2010; 86: 345-96. [CrossRef]

34. Baik HW, Russell RM. Vitamin B12 deficiency in the elderly. Annu Rev Nutr 1999; 19: 357-77. [CrossRef]

35. Gräsbeck R. Biochemistry and clinical chemistry of vitamin B12 transport and the related diseases. Clin Biochem 1984; 17: 99-107. [CrossRef]

36. Aoganghua A, Nishiumi S, Kobayashi K, Nishida M, Kuramochi K, Tsubaki $\mathrm{K}$, et al. Inhibitory effects of vitamin $\mathrm{K} 3$ derivatives on DNA polymerase and inflammatory activity Int J Mol Med 2011; 28: 937-45.

37. Pirouzpanah S, Rashidi MR, Delazar A, Razavieh SV, Hamidi A. Inhibitory effects of Ruta graveolens $L$. extract on guinea pig liver aldehyde oxidase. Chem Pharm Bull 2006; 54: 9-13. [CrossRef]

38. Mraz CE, Muresan M, Micle O, Vicas L, Pallag A, Coltau M, et al. Effect of vitamin $d$ on carbonic anhydrase activity experimental reasearch in vitro and in vivo. Farmacia 2012; 60: 264-71.

39. Anderson PH, Turner AG, Morris HA. Vitamin D actions to regulate calcium and skeletal homeostasis. Clin Biochem 2012; 45: 880-6. [CrossRef] 